\title{
GAMBARAN MALOKLUSI DAN KEBIASAAN BURUK PENDERITA SINDROM DOWN USIA 6-18 TAHUN DI SLB-C KOTA MEDAN
}

\author{
(DESCRIPTION OF MALOCCLUSION AND BAD HABIT AMONG DOWN \\ SYNDROME CHILDREN AGE 6-18 YEARS IN SCHOOL FOR \\ DISABILITIES IN MEDAN CITY)
}

\author{
Siti Salmiah, Nurul Sukma Mustafa \\ Departemen Pedodonsia \\ Fakultas Kedokteran Gigi, Universitas Sumatera Utara \\ Jl. Alumni No.2 Kampus UeSU Medan 20155 \\ E-mail: salmiahdentist@yahoo.com
}

\begin{abstract}
Down syndrome is one of a kind of mental retardation caused by genetic or chromosomal problem and most prevalent among any type of mental retardation. This syndrome is easily noticed by combination between mental retardation and special physical characteristic like malocclusion. It is known that oral habit is one of the etiologies of malocclusion. The aim of this research was to know the prevalence of malocclusion and bad habit in Down syndrome a total of children age 6-18 years in school for disabilities in Medan. A descriptive survey was performed of 82 Down syndrome children age 618 years old who had registered as students in the 8 schools of disabilities in Medan were participated in this research. Data collected by interview with the parents and tha children had oral clinical examination. The result showed the prevalence of malocclusion according to Angle's classification, Class I 31, 71\%, Class II 3, 66\%, and Class III 48, $78 \%$. Type of malocclusion which was most prevalent was anterior crossbite $42,68 \%$, crowding $39,02 \%$, anterior openbite 23 , $17 \%$, and posterior crossbite $21,95 \%$. Prevalence of oral habit such as tongue thrusting was $41,46 \%$, mouth breathing 40 , $24 \%$, bruxism $37,8 \%$, finger sucking $36,58 \%$, and nail or finger biting $21,95 \%$. Parents are expected to consider this by minimalizing bad oral habit to reduce the percentage of malocclusion so the children might have swallowing and phonetic functions optimally. This research showed that high prevalence of these bad habits leads to a high prevalence of malocclusion in people with Down syndrome.
\end{abstract}

Key words: down syndrome, malocclussion, oral habit

\begin{abstract}
Abstrak
Sindrom Down merupakan salah satu bentuk retardasi mental akibat kelainan genetik atau kelainan kromosom yang paling sering terjadi.Sindrom ini dapat ditandai dengan retardasi mental dan karakteristik fisik yang khas seperti maloklusi sebagai salah satu manifestasi oral khas pada penderita ini.Maloklusi sendiri memiliki berbagai faktor etiologi, salah satunya kebiasaan buruk. Tujuan penelitian ini adalah untuk mengetahui prevalensi maloklusi dan kebiasaan buruk pada anak sindrom Down usia 6-18 Tahun di SLB-C Kota Medan.Jenis penelitian ini adalah survei deskriptif. Jumlah sampel penelitian ini sebesar 82 anak usia 6-18 tahun yang merupakan jumlah seluruh anak sindrom Down yang bersekolah di 8 SLB-C yang ada di Kota Medan. Pengambilan data dilakukan dengan wawancara terhadap orang tua dan pemeriksaan klinis pada rongga mulut anak. Analisis data dilakukan dengan cara manual dan komputerisasi. Data distribusi disajikan dalam bentuk tabel dengan hasil persentase. Hasil penelitian ini mendapatkan prevalensi maloklusi berdasarkan klasifikasi Angle pada anak sindrom Down usia 6-18 tahun di SLB-C Kota Medan sebesar 31,71\% anak memiliki hubungan molar Klas I, 3,66\% Klas II, dan 48,78\% Klas III. Bentuk maloklusi paling banyak adalah gigitan silang anterior yaitu 42,68\%, diikuti oleh crowding 39,02\%, gigitan terbuka anterior sebanyak 23,17\%, dan gigitan silang posterior 21,95\%. Kebiasaan buruk paling tinggi adalah tongue thrusting yaitu 41,46\%, bernapas melalui mulut 40,24\%, bruxism 37,8\%, menghisap jari 36,58\%, dan menggigit kuku atau jari 21,95\%. Prevalensi maloklusi dan kebiasaan buruk pada anak sindrom Down ini tergolong cukup tinggi. Hal ini perlu menjadi perhatian orang tua/wali/pengasuh untuk meminimalisir kebiasaan buruk tersebut agar pengunyahan dan fonetik anak dapat berfungsi dengan optimal. Penelitian ini menunjukkan bahwa tingginya prevalensi kebiasaan buruk tersebut menyebabkan tingginya prevalensi maloklusi pada penderita sindrom Down.
\end{abstract}


Kata kunci: sindrom down, maloklusi, kebiasaan buruk

\section{PENDAHULUAN}

Sindrom Down pertama kali dideskripsikan oleh seorang dokter dari Inggris bernama Langdon Down pada tahun 1866. ${ }^{1,2}$ Sindrom ini disebabkan oleh anomali kongenital kromosom autosomal (non-sex chromosome) pada kromosom $21 .{ }^{1-3}$ Sindrom Down merupakan kelainan kromosom pada kelahiran yang cukup sering terjadi di dunia. WHO melaporkan, estimasi insidensinya berada antara 1 dari 1.000 hingga 1 dari 1.100 kelahiran. Penderitanya saat ini berjumlah 8 juta di dunia. Setiap tahun diperkirakan terdapat 3.000 hingga 5.000 anak terlahir dengan sindrom Down dan terdapat sekitar 250.000 keluarga di Amerika Serikat yang salah satu anggota keluarganya menderita sindrom ini. ${ }^{3}$ Data terbaru dari RISKESDAS 2013 menyatakan bahwa hingga kini telah terdapat 300.000 kasus anak yang mengalami sindrom Down di Indonesia. ${ }^{4}$

Retardasi mental bisa didefinisikan sebagai kemampuan intelektual yang signifikan di bawah ratarata. Keadaan ini bisa didiagnosa dari hasil tes IQ yang menunjukkan hasil yang berkisar antara 70 hingga kurang dari 20. Kondisi ini akan sangat mempengaruhi individu dalam melakukan aktivitas sehari-harinya. Mereka memiliki kemampuan berkomunikasi, merawat diri, menjaga keselamatan diri, melakukan aktivitas di rumah, kemampuan sosial, intrapersonal, perkerjaan, penggunaan transportasi dan teknologi serta kemampuan akademik yang sangat rendah dibandingkan kemampuan rata-rata individu di usianya. Di balik keterbelakangan mental tersebut, anak sindrom Down dikenal sebagai sindrom dengan kemampuan sosial yang cukup baik. ${ }^{5,6}$

Karakteristik fisik sindrom Down secara umum ditandai dengan lemahnya kemampuan tonus otot, wajah datar, ujung mata tertarik agak ke atas, kemampuan pergerakan sendi yang berlebihan, bentuk telinga yang tidak beraturan, dan jarak yang lebar antar ibu jari kaki dan jari di sebelahnya. Manifestasi oral anak dengan sindrom ini antara lain kebiasaan bernapas dari mulut sehingga palatumnya tinggi dan sempit, makroglosia, lidah dan bibir yang berfisur, anomali dental, maloklusi, oral hygiene yang buruk, dan insidensi karies yang rendah. Adapun kelainan orofasial yang ditemukan adalah pertumbuhan wajah sepertiga tengah yang terhambat sehingga ditemukannya tinggi hidung yang pendek, hipoplastik maksila, dan mandibula yang prognatik. Hal tersebut menyebabkan terjadinya Klas III dental dan skeletal pada anak sindrom Down. ${ }^{1-3,7}$
Penelitian Mestrovic dkk. di Kroasia membuktikan bahwa terdapat prevalensi maloklusi sangat tinggi pada anak Sindrom Down yaitu 92\%, sedangkan yang tidak mengalami maloklusi hanya $8 \% .{ }^{8}$ Selanjutnya, Danielle Bauer dkk. dengan menggunakan metode PAR dan ICON meneliti anak dengan sindrom Down dan memperoleh kesimpulan bahwa mereka memiliki insiden maloklusi lebih tinggi dibandingkan anak yang tidak menderita sindrom Down. ${ }^{1}$ Maloklusi tidak lepas dari kebiasaan buruk pada rongga mulut sebagai salah satu etiologinya.

Kebiasaan buruk yang dialami baik anak normal maupun anak sindrom Down memiliki rentang prevalensi yang bervariasi mulai dari 20-92\%. ${ }^{9}$ Penelitian yang dilakukan pada ras bahkan negara yang sama tidak menjadi jaminan dekatnya hasil angka prevalensi kebiasaan buruk ini. Oleh karena masih sedikitnya penelitian yang dilakukan dan belum tersedianya data yang lengkap mengenai maloklusi pada anak sindrom Down di Indonesia khususnya di kota Medan, serta variatifnya angka prevalensi kebiasaan buruk pada berbagai populasi anak, maka penelitian ini bertujuan untuk mengekplorasi gambaran maloklusi dan kebiasaan buruk pada penderita sindrom Down usia 6-16 tahun di SLB-C kota Medan.

\section{BAHAN DAN METODE}

Penelitian ini merupakan survei deskriptif dengan pendekatan cross-sectional. Sampel yang digunakan adalah seluruh populasi (total sampling) pada anak sindrom Down usia 6-18 tahun di SLB-C Kota Medan.

Pada penelitian ini, maloklusi yang akan diteliti meliputi maloklusi hubungan molar berdasarkan klasifikasi Angle dan berbagai bentuk umumnya yang bisa diamati secara klinis seperti gigitan silanganterior dan posterior, gigitan terbuka anterior, dan crowding, dan jenis kebiasaan buruk yang umum dialami anak seperti bernapas melalui mulut, tongue thrusting, menggigit kuku atau jari, menghisap jari, dan bruxism.

Pertama sekali peneliti membagikan lembar penjelasan kepada calon subjek penelitian dan informed consent untuk ditandatangani seraya mewawancara orang tua/wali/pengasuh mengenai berbagai kebiasaan buruk yang dimiliki anak. Selanjutnya peneliti melakukan pemeriksaan rongga mulut penderita untuk melihat maloklusi dan menanyakan berbagai jenis kebiasaan buruk. 


\section{HASIL}

Subjek penelitian berjumlah 82 orang terdiri atas 50 anak laki-laki $(60,97 \%)$ dan 32 anak perempuan $(39,03 \%)$. Berdasarkan usia, anak yang sedang dalam fase gigi ber-campur yakni 6-11 tahun berjumlah 36 anak $(43,9 \%)$ dan anak yang sedang dalam fase usia gigi permanen berjumlah 46 anak $(56,1 \%)$ (Tabel 1).

Tabel 1. Distribusi karakteristik responden anak sindrom Down di SLB-C Kota Medan ( $\mathrm{n}=82)$

\begin{tabular}{|c|c|c|}
\hline Karakterisik responden & Jumlah (n) & Persentase $(\%)$ \\
\hline \multicolumn{3}{|l|}{ Jenis Kelamin } \\
\hline Laki-laki & 50 & 60,97 \\
\hline Perempuan & 32 & 39,03 \\
\hline \multicolumn{3}{|l|}{ Usia } \\
\hline 6-11 Tahun (fase gigi bercampur) & 36 & 43,9 \\
\hline 12-18 Tahun (fase gigi permanen) & 46 & 56,1 \\
\hline Total & 82 & 100 \\
\hline
\end{tabular}

Sebanyak $13(15,85 \%)$ anak belum memiliki gigi M1 yang sudah erupsi hingga mencapai dataran oklusal atau sudah tidak lagi memiliki gigi M1 (missing), sehingga relasi hubungan molar pada anak tersebut tidak dapat ditentukan.

Dari 69 sampel penderita sindrom Down yang gigi M1 sudah erupsi hingga mencapai dataran oklusal, diperoleh 26 anak $(31,71 \%)$ memiliki hubungan molar Klas I. Sebanyak 3 orang anak $(3,66 \%)$ memiliki hubungan molar Klas II. Hubungan molar Klas III didapati pada 40 anak (48,78\%) (Gambar 1).

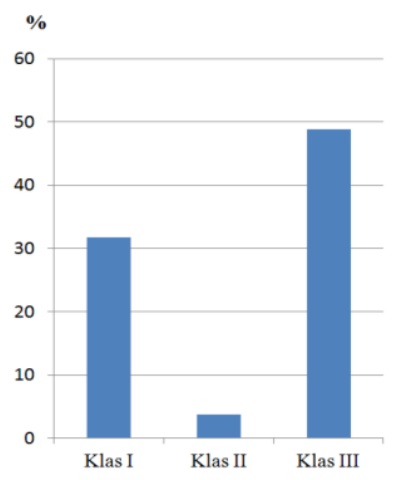

Gambar 1. Prevalensi maloklusi klasifikasi Angle pada anak sindrom Down berdasarkan jenis kelamin usia 6-18 tahun di SLB-C Kota Medan

Sebanyak 19 anak $(23,17 \%)$ yang memiliki gigitan terbuka anterior. Selanjutnya, didapati 35 anak $(42,68 \%)$ memiliki gigitan silang anterior. Gigitan silangposterior didapati pada 18 anak $(21,95 \%)$, dan crowding didapati pada 32 anak (39,02\%) (Gambar 2).

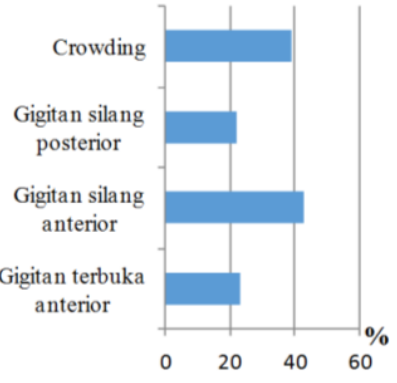

Gambar 2. Distribusi prevalensi bentuk maloklusi pada anak sindrom Down berdasarkan jenis kelamin usia 6-18 tahun di SLB-C Kota Medan

Kebiasaan buruk yang dialami oleh anak sindrom Down, 33 anak $(40,24 \%)$ bernapas melalui mulut, 34 anak $(41,46 \%)$ tongue thrusting, 18 anak $(21,95 \%)$ menggigit kuku atau jari, 30 anak (36,58\%) menghisap jari, 31 anak (37,8\%) bruxism (Gambar 3).

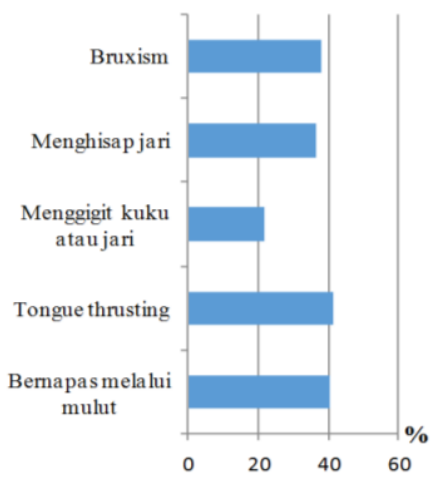

Gambar 3. Distribusi prevalensi kebiasaan buruk pada anak sindrom Down berdasarkan jenis kelamin usia 6-18 tahun di SLB-C Kota Medan

\section{PEMBAHASAN}

Prevalensi maloklusi berdasarkan klasifikasi Angle pada anak sindrom Down usia 6-18 tahun di SLB-C Kota Medan yang paling tinggi adalah Klas III sebesar 48,78\%, diikuti oleh Klas I 31,71\%, dan yang paling sedikit adalah Klas II sebesar 3,66\%. Dibandingkan dengan penelitian Bauer dkk. di Amerika Serikat angka prevalensi Klas III juga lebih tinggi yaitu $56,7 \%$ dibandingkan dengan Klas I sebanyak 23,3\%, dan Klas II sebanyak 10\%. Hal tersebut mendukung pernyataan tentang anak sindrom Down yang memiliki defisiensi pembentukan maksila yang tidak seiring dengan pertumbuhan mandibula sehingga sering ditemukan mandibula yang prognatik. ${ }^{1,2,9,13}$

Namun, adanya perbedaan prevalensi antara penelitian ini dengan penelitian Bauer dkk. terjadi kemungkinan akibat perbedaan ras antar responden pada kedua penelitian ini. Pada penelitian Bauer dkk. Kemungkinan banyak melibatkan ras kaukasian. Me- 
nurut literatur, ras kaukasian memiliki profil wajah yang lebih condong prognatik dibandingkan ras mongoloid sehingga lebih berpotensi memiliki hubungan Klas III dibandingkan sampel pada penelitian ini. $^{14}$

Pada penelitian ini, gigitan silang anterior merupakan bentuk maloklusi yang paling banyak ditemukan pada anak sindrom Down yaitu sebanyak 42,68\%. Hal tersebut sesuai dengan penelitian Oliveira dkk. yang juga menemukan gigitan silang anterior sebagai bentuk maloklusi paling tinggi pada anak sindrom Down dengan persentase 33\%. Keadaan ini dapat terjadi akibat proklinasi gigi-gigi mandibula yang umum ditemukan pada anak sindrom Down. Sebagaimana yang telah dijelaskan sebelumnya, anak sindrom Down umumnya memiliki hubungan rahang Klas III, hal ini juga dapat menyebabkan posisi gigi mandibula lebih protrusif sehingga terbentuklah gigitan silang anterior pada anak sindrom Down. ${ }^{9}$

Bentuk maloklusi paling umum dijumpai pada anak sindrom Down setelah gigitan silang anterior adalah crowding yaitu sebanyak 39,02\%. Hasil ini sesuai dengan hasil penelitian yang dilakukan oleh Mestrovic dkk. yang menempatkan crowding sebagai bentuk maloklusi tertinggi kedua pada anak sindrom Down. Akan tetapi, hasil jauh lebih tinggi dibandingkan hasil penelitian yang dilakukan oleh Mestrovic dkk. yang mana pada penelitian tersebut hanya sebesar $17 \% .^{8}$ Berdasarkan hasil pengamatan di la-pangan, tingginya crowding ini diakibatkan oleh ba-nyak di antara sampel yang memiliki gigi persistensi dan orang tuanya tidak berani membawa anaknya ke dokter gigi untuk mengatasi hal tersebut. Selain itu, beberapa anak sindrom Down pada penelitian ini juga banyak ditemukan memiliki ukuran rahang yang kecil tanpa diiringi oleh pertumbuhan gigi permanen yang mengalami anomali dental seperti mikrodonsia, peg shape, hipodonsia, dll. Keadaan-keadaan tersebut mengakibatkan posisi gigi berjejal. ${ }^{8,10,15}$

Bentuk maloklusi lainnya yang dialami anak sindrom Down pada penelitian ini adalah gigitan terbuka anterior dan gigitan silang posterior masingmasing $23,17 \%$ dan $21,95 \%$. Salah satu penelitian Oliveira dkk. menunjukkan angka prevalensi yang mendekati dengan hasil penelitian ini yaitu sebesar $21 \%$ untuk gigitan terbuka anterior dan hasil gigitan silang posterior yang juga sangat mendekati hasil penelitian ini yaitu sebesar 21,5\%. Bentuk maloklusi ini dipengaruhi oleh pola pertumbuhan skeletal dan berbagai kebiasaan buruk yang dimiliki anak. Selain itu, kebiasaan buruk seperti tongue thrusting, menghisap jari, menggigit kuku atau jari, dan bernapas melalui mulut sangat berperan dalam merubah posisi gigi sehingga terbentuk berbagai jenis maloklusi tersebut. $^{16,17}$
Penderita sindrom Down juga memiliki berbagai jenis kebiasaan buruk. Penelitian ini memperoleh hasil tongue thrusting sebagai kebiasaan buruk yang paling banyak dimiliki oleh anak sindrom Down yaitu sebesar $41,46 \%$. Hasil ini sesuai dengan prevalensi yang dimiliki oleh anak sindrom Down di Chennai pada tahun 2008 yaitu 41,2\%. Prevalensi ini tergolong cukup tinggi kemungkinan disebabkan oleh kondisi anak sindrom Down yang memiliki lidah yang protrusif ditambah kondisi hipotonus yang mereka alami sehingga sulitnya mengontrol gerakan lidah di dalam rongga mulut mereka., ${ }^{2,13}$

Kebiasaan buruk berikutnya adalah bernapas melalui mulut dengan prevalensi 40,24\%. Angka ini sangat berbeda dengan hasil penelitian Oliveira dkk. yang hanya memperoleh hasil sebesar 9\% disebabkan pada penelitian di Brazil tersebut, mayoritas sampel pernah menjalani operasi tonsil dan adenoid akibat obstruksi saluran nafas atas sehingga menghasilkan prevalensi bernapas melalui mulut yang rendah. ${ }^{16,17}$ Ini membuktikan bahwa anak sindrom Down tersebut belum sepenuhnya mampu mengubah postur mulutnya sehingga mengarahkan mereka kembali ke kebiasaan bernafas melalui mulut. Namun, Hannequin dkk. memperoleh prevalensi bernapas melalui mulut yang juga cukup tinggi pada anak sindrom Down sebesar 64,2\%. ${ }^{18}$ Perbedaan tersebut dimungkinkan oleh perbedaan distribusi usia sampel yang terlibat kedua penelitian ini. Anak sindrom Down banyak yang sering bernapas melalui mulut salah satunya dikarenakan pertumbuhan sepertiga wajahnya yang lebih pendek sehingga memiliki saluran pernapasan dari hidung yang lebih sempit. ${ }^{2,918}$

Bruxism merupakan salah satu kebiasaan buruk yang dilaporkan cukup sering dialami oleh anak sindrom Down. Pada penelitian ini, bruxism pada anak sindrom Down sebesar 37,8\%. Hasil pada penelitian ini mendekati dengan hasil penelitian yang dilakukan oleh Bauer dkk. dengan persentase 33,3\%. ${ }^{1} \mathrm{Me}-$ nurut Miamoto dkk. prevalensi bruxism pada anak sindrom Down bisa sangat bervariatif mulai dari 390\%. Hal ini disebabkan oleh etiologi bruxism yang belum pasti, masih berupa faktor risiko mulai dari genetik, psikologis, neurologis, faktor sistemik, dan keadaan sosial. Hipotonus yang mengarah pada ketidakstabilan otot dan rahang serta kondisi sistemik juga turut berperan dalam memicu tingginya prevalensi bruxism ini. Selain itu, anak sindrom Down sering dikucilkan atau dianggap orang "lain" di beberapa tempat atau suatu kelompok masyarakat tertentu dan terkadang dalam keluarga, hal ini merupakan salah satu predisposisi dari segi keadaan sosial yang memicu stres sehingga timbulnya kebiasaan buruk ini. ${ }^{1,19}$ 
Menghisap jari dan menggigit kuku atau jari merupakan jenis kebiasaan yang bisa dialami siapa saja. Kebiasaan buruk tersebut dimasukkan dalam penelitian ini karena merupakan jenis kebiasaan buruk parafungsional yang sering memberikan dampak cukup signifikan terhadap terbentuknya maloklusi. Pada penelitian ini, diperoleh hasil prevalensi menghisap jari dan menggigit kuku atau jari sebesar 36,58\% dan $21,95 \%$. Oliveira dkk. memperoleh hasil $17 \%$ untuk menghisap jari dan $42 \%$ untuk kebiasaan menggigit kuku atau jari. ${ }^{9}$ Oleh karena kebiasaan ini bukan merupakan kebiasaan khas pada anak sindrom

\section{DAFTAR PUSTAKA}

1. Bauer D, Evans CA, BeGole EA, Salzman L. Severity of occlusal disharmonies in Down syndrome. Int J Dent 2012; 2012: 1-6.

2. Ronald HWC, Yiu CKY, Leung WK. Oral health in individuals with down syndrome. Shanghai: InTech China. 2011: 59-71.

3. World Health Organization. Gens and human disease. <http:/www.who.int/genomics/public/genetic disease/en/index1.html.> (16 Agustus 2014).

4. Badan Penelitian dan Pengembangan Kesehatan. Riset Kesehatan Dasar 2013. Jakarta. 2013: 188-9.

5. Nolen-Hoeksema S. Abnormal psychology. $4^{\text {th }}$ ed., New York: The McGraw Hill. 2007: 438-91.

6. Haugaard JJ. Child psychopatology. New York: The McGraw Hill; 2008: 412-49.

7. Irdawati, Muhlisin A. Sindrom Down pada anak ditinjau dari segi biomedik dan penatalaksanaannya. Berita Ilmu Keperawatan 2009; 2(1): 47-50.

8. Mestrovic S, Miksic M, Stefanac-Papic J, Stipetic J. Prevalence of malocclusion with Down's syndrome. Acta Stomatol Croat 2002; 36(2): 239-41.

9. Oliveira ACB, Paiva SM, Campos MR, Czeresnia D. Factors associated with malocclusion in children and adolescents with Down syndrome. Am J Orthod Dentofacial Orthop 2007; 133(4): 489-97.

10. Iyyer BS. Orthodontics the art and science. $4^{\text {th }}$ ed., New Delhi: Arya (Medi) Publishing House. 2009: 119-59.

11. Cobourne MT, DiBiase AT. Handbook of orthodontics. Philadelphia: Mosby Elsevier, 2010: 11-7.
Down atau kelainan mental lainnya, maka tidak ada rentang angka prevalensi yang pasti. Berbagai kebiasaan buruk tersebut seperti tongue thrusting, menggigit kuku, dan menghisap jari dapat memberikan gaya atau tekanan secara kontinyu sehingga perlahan mampu memberikan dorongan bagi gigi geligi sehingga berubah posisinya menjadi lebih protrusif. ${ }^{10}$ Teori ini mendukung hasil pada penelitian ini yang menunjukkan tingginya prevalensi kebiasaan buruk tersebut dan tingginya prevalensi maloklusi pada penderita sindrom Down.

12. Singh G. Textbook of orthodontics. New Delhi: Jaypee Brothers Medical Publishers. 2007: 48-37, 153-99.

13. Asokan S, Muthu MS, Sivakumar N. Oral findings of Down syndrome children in Chennai city, India. Indian J Dent Res 2008; 19(3): 230-5.

14. Albarakati SF. Soft tissue facial profile of adult Saudis: lateral cephalometric analysis. Saudi Med J 2011; 32(8): 836-42.

15. McDonald RE, Avery DR, Dean JA. Eruption of the teeth: local, systemic and congenital factors that influence the process. In: McDonald RE, Avery DR, Dean JA. eds. Dentistry for the child and adolescent. $8^{\text {th }}$ ed., Missouri: Mosby. 2004: 190-4.

16. Oliveira AC, Pordeus IA, Torres CS, Martins MT, Paiva SM. Feeding and non-nutritive sucking habits and prevalence of open bite and crossbite in children/adolescents with Down syndrome. Angle Orthod 2010; 80(4): 748-52.

17. Oliveira AC, Paiva SM, Martins MT, Torres CS, Pordeus IA. Prevalence and determinant factors of malocclusion in children with special needs. Eur $\mathbf{J}$ Orthod 2011; 33(4): 413-8.

18. Hannequin M, Allison PJ, Veyrune JL. Prevalence of oral health problems in a group of individuals with Down syndrome in France. Dev Med Child Neurol 2000; 42: 691-8.

19. Miamoto CB. Prevalence and predictive factors of sleep bruxism in children with and without cognitive impairment. Braz Oral Res 2011; 25(5): 1-7. 